\title{
EFFECT OF RIDGE SPACING AND PLANT DENSITY FOR TWO MAIZE HYBRIDS
}

Attia, A. N. E. *; S. A. EL - Moursy *; G. M. A. Mahgoub** and

M.M. B. Darwich**

* Agron. Dept., Fac. Agric., Mansoura Univ.

** National Maize Res. Program, Field Research, ARC, Giza, Egypt.

\section{ABSTRACT}

Two field experiments were carried out at the Experimental Farm of Gemmeiza Agricultural Research Stations during 2007 and 2008 seasons to study the effect of row spacing, i.e. $(60,70$ and $80 \mathrm{~cm}$ apart) and plant density, i.e. (20000, 25000 and 30000 plants/fed.) on growth, yield and yield components of two maize hybrids, i.e. (S.C125 and S.C162). A split-split plot design with four replicates was used in the two experiments.

- Results showed that increasing ridge spacing significantly recorded No. of days two $50 \%$ tassling and silking, plant and ear heights were in the same direction planting on $80-\mathrm{cm}$ ridge was associated with a significant increase in ear length, No. of kernels/row, 1000 kernels weight and grain yield (ard/fed).

- On the other side, plant density of 25000 plant/fed was associated with the highest grain yield and its component as soon as it is considered of the optimum environmental.

- Single cross 125 was earlier than single cross 162 of days to $50 \%$ tassling and silking. S.C. 125 had the best effects of plant and ear height towards low ear position, 1000 kernels weight, S.C. 162 gave the highest values of No. of ear length kernels/row and grain yield. (Ridge spacing $x$ plant density interaction was significant for No. of days to $50 \%$ tassling and silking, plant and ear heights, No. of kernels/row. Plant density $\mathrm{x}$ hybrid interaction was significant for plant height, ear length, 1000 kernels weight (g) and grain yield ard./fed).

- This investigation showed that planting on $80-\mathrm{cm}$ rows at plant density of 25000 plants/fed (25- $\mathrm{cm}$ between hills) in order to obtain the highest grain yield. This would also facilitate using the mechanization and saving costs, time, and effort.

\section{INTRODUCTION}

Maize (zea mays L.) is considered of important cereal crop in Egypt and the world, where, it ranged after wheat and rice from the importance. It is widely used (zea mays L.) in bread manufacture intural areas of the country because it conform the basis for several industries such as starch, fructose, corn flakes, alcohol, corn oil, corn sugar, corn fiber (soronoa), ethanol and biobutanol as well as the main component (about $70 \%$ ) of animal feed in Egypt, it is necessary to increase maize yield to face the wide gab between the production and consumption. High maize production can be achieved by improving cultural practices and planting the promising hybrids. Corn agronomists continually search for methods that help them to increase grain yield and net return of producing the crop plant density and row spacing affect plant distribution in field. Currently maize practices in Egypt recommend planting maize in hills on $70 \mathrm{~cm}$ between rows and $25-30 \mathrm{~cm}$ 
Attia, A. N. E. et al.

between hills (within row). Brown et al. (1970), recorded a that $33.7 \%$ yield increase for corn grown in $51 \mathrm{~cm}$ rows compared with $102 \mathrm{~cm}$ between rows. Fulton (1970), revealed that higher plant densities (54.362 plants ha-1) produced higher yields than lower densities (36.536 plants ha-1), and rows spaced at $50 \mathrm{~cm}$ produced higher yields than rows paced $100 \mathrm{~cm}$ apart Lutz et al. (1971), reported $5 \%$ yield increase for $76 \mathrm{~cm}$ between ridge spacing corn parded with $102 \mathrm{~cm}$ row spacing and an additional $2.7 \%$ yield adventage for $38 \mathrm{~cm}$. ridge spacing. younis et al. (1989), Ragheb et al. (1993), revealed that $60 \mathrm{~cm}$ rows were associated with higher grain yield compared with 70 or $80 \mathrm{~cm}$ rows. Grain yield increase in response to narrows rows closely related to the improvement in light interception during the critical period for grain set. Optimum plant distribution would play an important role in distributing plants more equidistantly across the field and reduced interplant competition. Sharief (2001) shown that increasing plant population density of maize spacing $51-60 \mathrm{~cm}$ and hill spacing of $25-30 \mathrm{~cm}$ apart gave plant density for maximizing grain yield per unit area ridge spacing optimum plant density depending on ridge spacing, density pattern sowing date and hybrids. In addition, plant density $x$ row spacing $(50 \mathrm{~cm})$ interaction in only one of four experimental years, indicate that the effect of narrow row spacing was greater at high plant densities that at low plant densities.

The objective of this investigation was to study the response of two new maize crosses i.e. S.C. 125, white new commercial hybrid and yellow single cross hybrids S.C. 162 to ridges spacing $(60,70$ and $80 \mathrm{~cm})$ and three plant densities ( 20,25 and 30 thousand plants / fed).

\section{MATERIALS AND METHODS}

Two field Experiments were performed at the Experimental Farm of Gemmeiza Agriculture Research Station, Agricultural Research Center (ARC), Egypt during 2007 and 2008 growing seasons.

\section{Treatments:}

\section{Ridge spacing (S):}

Three row spacing, i.e., 60,70 and $80 \mathrm{~cm}$ apart.

$60 \mathrm{~cm}$ (divided into 17,21 and 26 hill/row respectively).

$70 \mathrm{~cm}$ (divided into 21,25 and 31 hill/row respectively).

$80 \mathrm{~cm}$ (divided into 23,29 and 34 hill/row respectively).

2. Plant density (D):

Three plant densities, i.e., 20000, 25000 and 30000 plants/fed.

3. White and yellow maize hybrids $(H)$ :

Split split plot design was used in this study with four replications. Three ridge spacing (S) were arranged in main plots, plant densities were arranged in sub plots and two hybrids were arranged in sub sub plots.

Each plot consists of 5 rows with $6 \mathrm{~m}$ length; the two outer rows number one and five were left as border rows. The row number 2 was left for vegetative samples. The two outer rows number one and five were left as border rows. The two row number three and four were left for yield and yield components. Maize grains were hand sown in hills at the rate of $2-3$ grains/hill using dry sowing method (Afir) on one side of the ridge with the 
above mentioned hill spacing during the third week of may in 2007 and 2008 seasons. The other agricultural practices were kept the same as normally practiced in maize fields according to the recommendation of ministry of Agriculture and land Reclamation, except for the factors under study. While, the studied characters were :

1. Days to $50 \%$ tassling : (number of days from sowing to $50 \%$ emergence of tassling)

2. Days to $50 \%$ silking : (number of days from sowing to $50 \%$ emergence of silking)

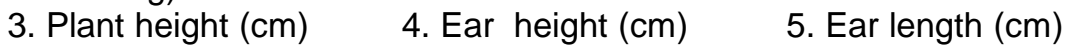

6. Number of kernels per row:

7. 1000 kernel weight $(\mathrm{g})$ :

8. Grain yield (ard./fed.): It was determined by the weight of grains per kilograms adjusted to 15.5 moisture content of each plot, then converted to ardab per feddan.

All data were statistically analysis according to the technique of analysis of variance (ANOVA) for the split split - plot design as published by Gomez and Gomez (1984) by means of " MSTAT - C" Computer software package. The treatment means were compared using least significant difference (LSD) method at $5 \%$ levels of probability according to the producer outlined by Waller and Duncan (1969).

\section{RESULTS AND DISCUSSION}

Means of days to $50 \%$ tasseling, silking, plant height and ear height as affected by ridge spacing, plant density of two maize hybrid and their interactions as show in Table (1):

\section{1- Effect of ridge spacing :}

Number of days to $50 \%$ tasseling and silking were significantly affected by ridge spacing in both seasons (2007and 2008). The earliest value of these traits were obtained at $60 \mathrm{~cm}$, while, the latest value was at $80 \mathrm{~cm}$. Plant height was significantly by row spacing in both seasons. ,while, ear height exhibited significant differences for row spacing in both seasons. The lowest value was at $60 \mathrm{~cm}$ apart between rows as shown in Table 1 . The hybrids had significant differences in 2007 season, but it was not significant in 2008 season, row spacing exhibited significant differences on number of kernels/row in 2008 season, but it was not significant in 2007 season. The highest value of number of kernels/row was obtained at row width $80 \mathrm{~cm}$, Increasing the distance among rows from 60 to $80 \mathrm{~cm}$ apart significantly increased 1000 kernels weight in 2007 season and ridge spacing exhibited significant differences on grain yield/fed. Where the higher values of grain yield/fed was at $80 \mathrm{~cm}$ apart between rows, while, the lower values were obtained at $60 \mathrm{~cm}$ apart between rows. These results were agreement with those Aly et al. (1996) and El- Koomy (2000), Atta-Allah (1996) and Mahgoub and El-Shenawy (2006) , Younis (1994), El-Habbak (1996), Mosalem (1998), El-Sheikh (2000), and Khalil (2001).

\section{2- Effect of plant density :}

Number of days to $50 \%$ tasseling and silking were affected by plant density in first season, plant density had no effect on plant height in 2007 
Attia, A. N. E. et al.

season but it had significant differences in 2008 season, ear height was not significant by plant density in both seasons as shown in Table 1., plant density was significant on ear length in both seasons where the highest value was at 20000 plant/fed, effect of plant density was not significant on number of kernels/row in both seasons, increasing plant density from 20000 to 30000 plant/fed led to significantly decreased 1000 kernels weight in 2007 season , Plant density exhibited significant differences in both seasons on grain yield/fed, where the plant density 25000 plant/fed gave the highest values of grain yield/fed. and it considered the optimum density or the optimum environmental as shown in Table 2.

3- Behavior of hybrids :

S.C. 125 was earlier than S.C. 162 in both seasons for to $50 \%$ tassling and silking, also the two hybrids exhibited the same effects and it was the same order on plant height trait, the highest value was obtained of ear height for S.C 162 , there was significant differences between two maize hybrids, where S.C 162 gave the highest value under two seasons comparing to S.C. 125 , maize hybrids showed significant differences on number of kernels/row in 2007 and 2008 seasons. S.C. 162 gave higher values on number of kernels/row comparing to S.C. 125 , the two hybrids exhibited significant differences on 1000 kernels weight where S.C. 125 gave the highest value of 500 kernels weight during the two seasons, the two maize hybrids exhibited significant differences for grain yield/fed. in both seasons. S.C. 162 gave the highest value of grain yield/fed. during the two seasons similar results were recorded, Meky (1993), Atta-Allah (1996) Mosalem (1998) Khalil et al. (2000) , El-Sheikh (2000), and Khalil (2001), Nawar et al. (1991), Younis et al. (1994), Aly et al. (1996), El-Zeir et al. (1998), Said and Gaber, (1999) and Hassan, (2000).

4- Interaction between factors :

The interactions between ridge spacing with hybrids and plant density on plant height were significant, also the interactions between hybrids and plant density were significant in both seasons, ear height was significantly affected by all interactions, except, interaction between maize hybrids and plant density, the interactions among all studied factors on 100 kernels weight was highly significant in both seasons, except the interaction between maize hybrids and plant density was significant in 2007 season and not significant in 2008 season, the interaction between the different factors exhibited significant differences, except, ridge spacing $\times$ plant density was not significant in 2008 season as reported by. Said and Gaber, (1999) and Hassan, (2000). Nawar et al. (1991), Younis et al. (1994), Aly et al. (1996), El-Zeir et al. (1998), Mosalem (1998), Khalil (2001), El-Habbak (1996), and Hassan et al. (2000). 
Table 1 : Number of days from sowing to $50 \%$ tasseling, silking , plant height $(\mathrm{cm})$ and ear height $(\mathrm{cm})$ as effected by ridge spacing, plant density and varieties performance as wells their interaction during 2007 and 2008 on seasons.

\begin{tabular}{|c|c|c|c|c|c|c|c|c|}
\hline \multirow{2}{*}{ Characters } & \multicolumn{2}{|c|}{$50 \%$ Tasseling } & \multicolumn{2}{|c|}{$50 \%$ Silking } & \multicolumn{2}{|c|}{ Plant height (cm) } & \multicolumn{2}{|c|}{ Ear height (cm) } \\
\hline & 2007 & 2008 & 2007 & 2008 & 2007 & 2008 & 2007 & 2008 \\
\hline \multicolumn{9}{|l|}{$\begin{array}{l}\text { A - Row spicing } \\
(\mathrm{cm})\end{array}$} \\
\hline $60(\mathrm{~cm})$ & 59.87 B & 60.37 B & 60.75 B & 60.37 B & $250.25 \quad$ B & 246.12 B & $138.12 \quad B$ & $139.41 \quad B$ \\
\hline $70(\mathrm{~cm})$ & $59.91 \quad$ B & $59.50 \mathrm{C}$ & $60.91 \mathrm{~B}$ & $59.50 \mathrm{C}$ & 248.12 B & $258.54 \quad A$ & $135.79 \quad \mathrm{~B}$ & 147.37 A \\
\hline $80(\mathrm{~cm})$ & $60.33 \mathrm{~A}$ & $61.08 \mathrm{~A}$ & $61.33 \mathrm{~A}$ & $61.08 \mathrm{~A}$ & 255.29 A & $260.62 \mathrm{~A}$ & $141.54 \quad \mathrm{~A}$ & $146.33 \mathrm{~A}$ \\
\hline F test & * & * & * & * & * & * & * & $\star$ \\
\hline \multicolumn{9}{|l|}{ B - Plant density } \\
\hline 20 & $59.83 \quad$ B & 60.45 & 60.83 B & 60.45 & 251.91 & $257.50 \mathrm{~A}$ & 138.83 & 143.62 \\
\hline 25 & 59.87 B & 59.87 & 60.87 B & 59.87 & 252.83 & 256.45 A & 139.54 & 145.45 \\
\hline 30 & $60.41 \mathrm{~A}$ & 60.62 & $61.29 A$ & 60.62 & 248.91 & $251.33 \quad$ B & 137.08 & 144.04 \\
\hline F test & * & NS & * & NS & NS & * & NS & NS \\
\hline \multicolumn{9}{|l|}{ C- Varieties } \\
\hline S.C. 125 & 59.30 & 59.94 & 60.25 & 59.94 & 245.33 & 252.13 & 135.63 & 144.80 \\
\hline S.C. 162 & 60.77 & 60.69 & 61.75 & 60.69 & 257.11 & 258.05 & 141.33 & 143.94 \\
\hline F test & * & * & * & * & N S & * & $\star$ & NS \\
\hline \multicolumn{9}{|l|}{ D- Interaction } \\
\hline$A \times B$ & $\star \star$ & * & * & * & * & $\star \star$ & $\star \star$ & $\star \star$ \\
\hline$A \times C$ & * & * & NS & * & 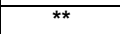 & $\star \star$ & $\star \star$ & $\star \star$ \\
\hline$B \times C$ & NS & NS & NS & NS & * & * & * & NS \\
\hline$A \times B \times C$ & $\star \star$ & NS & $\star \star$ & NS & 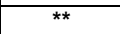 & $\star \star$ & $\star \star$ & $\star \star$ \\
\hline
\end{tabular}

Table 2: Number of days from sowing to ear length $(\mathrm{cm})$, no. of kernels/row , 500 kernels weight $(\mathrm{g})$ and grain yield (ard/fed) as effected by ridge spacing, plant density and varieties performance as wells their interaction during 2007 and 2008 on seasons.

\begin{tabular}{|c|c|c|c|c|c|c|c|c|}
\hline \multirow{2}{*}{ Treatments } & \multicolumn{2}{|c|}{$\begin{array}{l}\text { Ear length } \\
\text { (cm) }\end{array}$} & \multicolumn{2}{|c|}{$\begin{array}{c}\text { No. of } \\
\text { kernels/row }\end{array}$} & \multicolumn{2}{|c|}{$\begin{array}{c}1000-\text { Kernels weight } \\
\text { (gm.) }\end{array}$} & \multicolumn{2}{|c|}{ Grain yield (ard/fed) } \\
\hline & 2007 & 2008 & 2007 & 2008 & 2007 & 2008 & 2007 & 2008 \\
\hline \multicolumn{9}{|l|}{ A - Row spicing (cm) } \\
\hline $60(\mathrm{~cm})$ & 20.10 & $19.94 \quad \mathrm{~B}$ & 44.25 & $43.43 \mathrm{~B}$ & $358.66 \quad \mathrm{~B}$ & $319.50 \mathrm{~A}$ & $30.82 \mathrm{~B}$ & 27.75 B \\
\hline $70(\mathrm{~cm})$ & 20.41 & 20.12 B & 44.25 & 44.60 B & $365.24 \quad$ B & $288.04 \quad C$ & 31.55 B & 28.38 B \\
\hline $80(\mathrm{~cm})$ & 20.36 & $21.32 \mathrm{~A}$ & 44.45 & $46.17 \mathrm{~A}$ & $380.34 \mathrm{~A}$ & 305.16 B & $34.75 \mathrm{~A}$ & $31.51 \mathrm{~A}$ \\
\hline F test & NS & * & NS & * & * & * & * & * \\
\hline \multicolumn{9}{|l|}{ B - Plant density } \\
\hline 20 & $20.93 \mathrm{~A}$ & 20.76 A & 45.35 & 45.37 & $374.86 \mathrm{~A}$ & $311.64 \mathrm{~A}$ & $30.88 \mathrm{C}$ & $27.84 \mathrm{C}$ \\
\hline 25 & 20.61 A & 20.39 B & 44.72 & 44.57 & $368.32 \mathrm{~A}$ & 295.36 B & $33.80 \mathrm{~A}$ & $30.75 \mathrm{~A}$ \\
\hline 30 & $19.32 \mathrm{~B}$ & 20.23 B & 42.87 & 44.27 & $361.06 \quad \mathrm{~B}$ & $305.70 \mathrm{~A}$ & $32.43 \mathrm{~B}$ & 29.06 B \\
\hline F test & * & * & NS & NS & * & * & * & * \\
\hline \multicolumn{9}{|l|}{ C- Varieties } \\
\hline S.C. 125 & 18.87 & 19.08 & 43.89 & 43.40 & 372.96 & 312.24 & 29.18 & 27.31 \\
\hline S.C. 162 & 21.71 & 21.84 & 44.74 & 46.07 & 363.20 & 296.22 & 35.56 & 31.12 \\
\hline F test & * & * & * & * & * & * & * & * \\
\hline \multicolumn{9}{|l|}{ D- Interaction } \\
\hline$A \times B$ & * & * & NS & NS & $\star \star$ & ** & $\star \star$ & $\star \star$ \\
\hline$A \times C$ & N S & N S & ** & NS & $\star \star$ & ** & * & N S \\
\hline$B \times C$ & N S & * & NS & NS & * & N S & *夫 & * \\
\hline$A \times B \times C$ & N S & N S & * & NS & ** & $\star \star *$ & $\star \star$ & * \\
\hline
\end{tabular}




\section{REFERENCES}

Aly, A.M.; S.K. Bader and M.H.M. Grish (1996). Effect of variety, plant population and nitrogen application on grain yield of two maize varieties. Proc. $7^{\text {th }}$ Conf. Agron. 9-10 Sept. Mansoura Univ., Vol. 1: 7181.

Amer, E.A.; A.A. El-Shenawy; H.E. Mosa and A.A. Motawi (2004). Effect of spacing between rows and hills and number of plants per hill on growth, yield and its components of six maize crosses. J. Agric. Sci. Mansoura Univ., 2: 71-81.

Argenta, G.; P.R.F. da Silva; C.G. Bortolini; E.L. Forshthopfer, E.A. Manjabosco and Behergrary-Neto, V. (2001). Response of single-cross maize hybrids to reduced row spacing, Brasileire Agon. Dep. J. 36(1): 71-78.

Atta-Allah (1996). Effect of irrigation intervals and plant densities on growth, yield and its components of some maize varieties. Proc. $7^{\text {th }}$ Conf. Agron., 9-10 Sept. Mansoura Univ., Vol. 1: 71-80.

Bader, S.K.; A.M. Aly and M.N. Sherif (1993). Response of different maize genotypes to plant population density. Minufiya J. Agric. Res., 18(3): 1575-1582.

Barbieri, P.A.;I. H.R.S. Rozas; F.H. Andrade and H.E. Echeverria (2000). Row spacing effects at different levels of nitrogen availability in maize. Agron. J.. 92(2): 283-288.

Brown, R.H.; E.R.Beaty; W.J. Ethredge and D.D. Hayes (1970). Influence of row width and plant population on yield of two varieties of corn (Zea mays L.). Agron. J., 62: 767-770.

El-Habbak, K.E. and G.M. Shams El-Din (1996). Response of some maize genotypes to nitrogen fertilizer level. Annals of Agric Sci., Moshothor, 34(2): 529-547.

El-Koomy, M.B.A. (2000). CANOPY characteristics and yield of certain yellow maize hybrids as influenced by plant density M.Sc. Thesis, Fac. Agric. Ain Shams Univ. Egypt.

El-Zeir, F.A.; A.A. El-Shenawy; E.A. Amer and A.A. Galal (1998). Influence of narrow row spacing (high plant density) and nitrogen fertilization on two maize hybrids. J. Agric. Sci. Mansoura Univ., 233(5): 1855-1864.

Fulton, J.M. (1970). Relationships among soil moisture stress, plant populations row spacing, and yield of corn. Can. J. Plant Sci., 50: 3138.

Hassan, A.A. (2000). Effect of plant population density on yield and yield components of eight Egyptian maize hybrids Bull. Fac. Agric., Cairo Univ., 51: 1-16.

Khalil, M.A.G. (2001). Response of some yellow and white maize cultivars to plant densities and nitrogen fertilization. M.Sc. Thesis, Fac. Agric., Kafr El-Sheikh, Tanta Univ., Egypt.

Lutz, J.A.Jr.; H.M. Camper and G.D. Jones (1971). Row spacing and population effects on corn yields. Agron. J ; 63: 12-14. 
Mahgoub, G.M.A. and A.A. El-Shenawy (2006). Response of some maize hybrids to row spacing and plant density. $1^{\text {st }}$ Conf. 22-24 Aug., Field Cr. Res. Inst., ARC, Egypt, Conference Proceeding., 285-293.

Meky, M.S. (1993). Effect of some agricultural practices on growth, yield and its components of corn (Zea mays L.). M.Sc. Thesis, Fac. Agric., ElMinia Univ., Egypt.

Mohamed, N.A. (2004). Principle components and response curve analyses of some maize hybrids to different nitrogen fertilization levels and plant density. Bull. Fac. Agric., Cairo Univ., 55(4): 531-556.

Nawar, A.A.; H.A. Dawwam; M.E. Ibrahim and A.N.E. Khalil (1991). Effect of plant densities on phenoytpic and genotypic estimates in maize. J. Agric. Res. Tanta Univ., 17(2): 187-199.

Ragheb, M.M; A.A. Bedeer and A.Sh. Gouda (1993).Effect of row spacing and plant population density on grain yield of some maize hybrids. Zagazig J. Agric. Res., 20(2): 581-594.

Sharief, A.E.M. (2001). Plant population density as limited factor affecting production of cereal crops. J. Agric. Sci. Mansoura Univ., 26 (3) : 1219 $-1245$.

Younis, M.A.; S.M.M. Amer; A.H. Awad and Sh.F. Aboul Saad (1989). Effect of row spacing and plant population on maize grain yield. Egypt J. Appl. Sci., 4(3): 359-365.

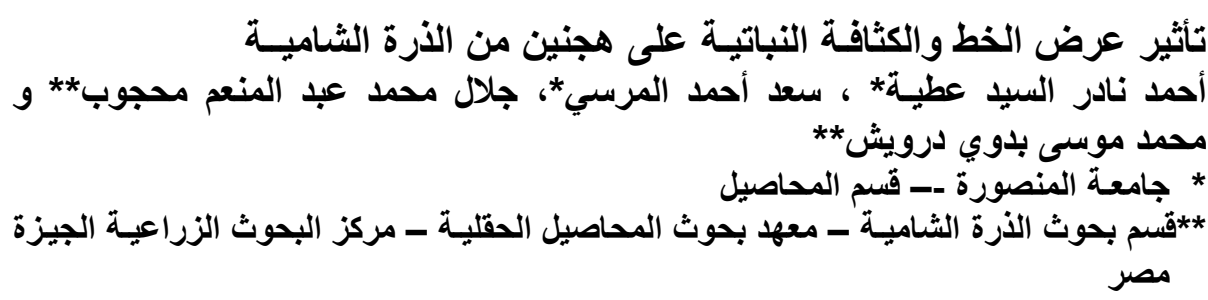

أجريت تجربتان حقليتان بالمزر عة البحثية بمحطة البحوث الزر اعية بالجميزة وذلك خلال

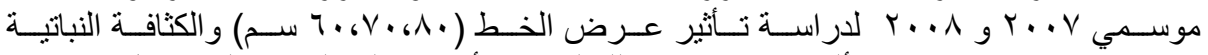

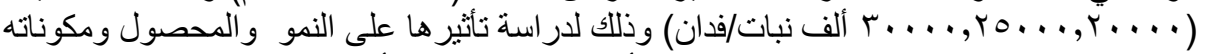

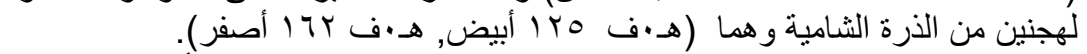
وكان التصميم المستخدم للتجربتين هو القطع المنشقة مرتين في أربع مكررات .

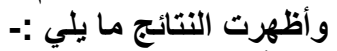

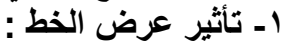

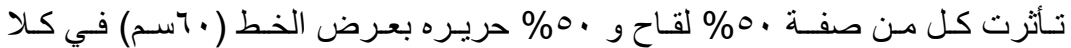

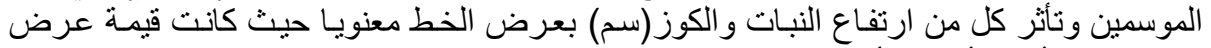

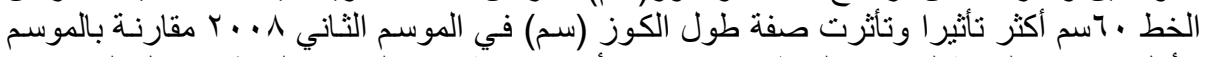

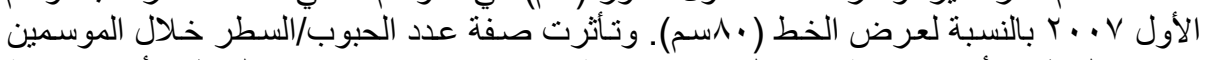

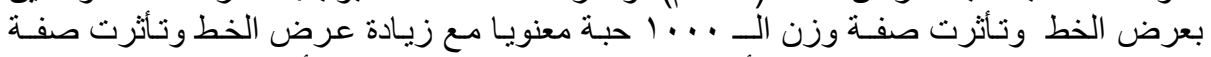
محصول الحبوب بعرض الخط حيث أعطت قيما عاليـة عند ، مسعم بينما الأقل عند . آسم.

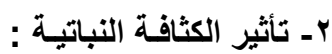


Attia, A. N. E. et al.

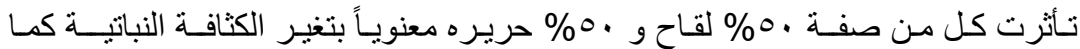

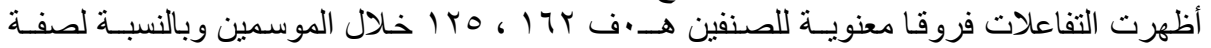

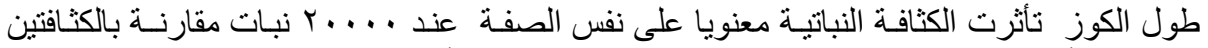

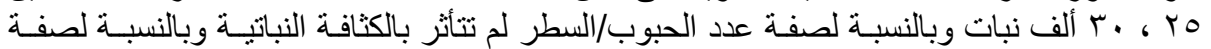

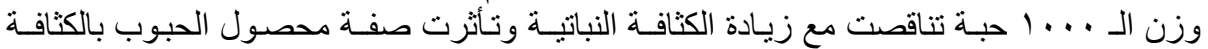
النباتيـة حيث كانت الكثافة النباتيـة ... . مب نبات الأعلى قيمـة للمحصول.

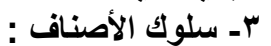

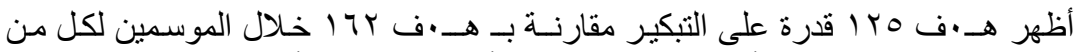

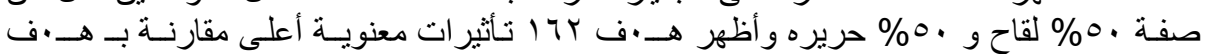

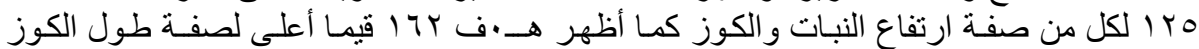

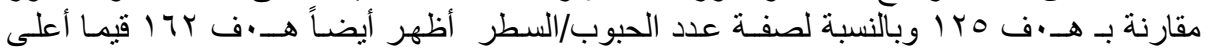

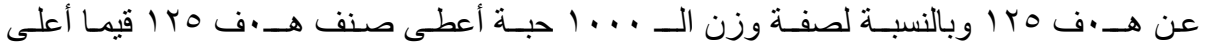

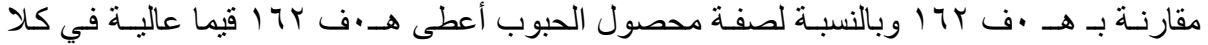

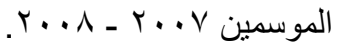

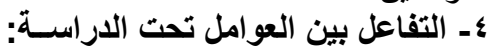

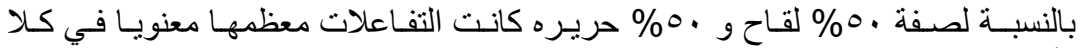

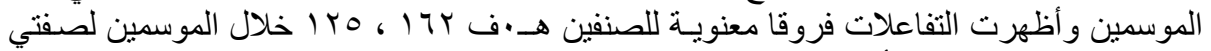

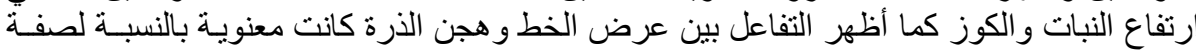

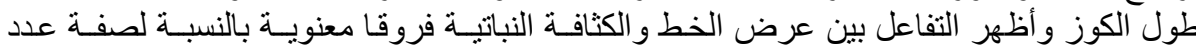

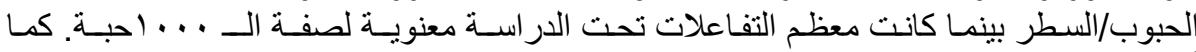

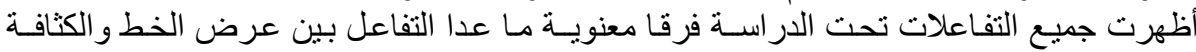

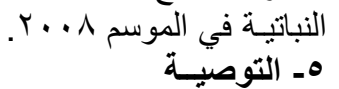

عموما من النتائج المتحصل عليها في هذه الدراسـة يمكن التوصيـة بزر اعـة الذرة الثـاميـة

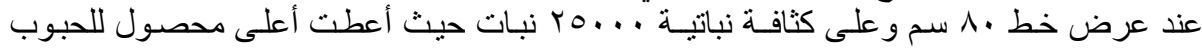
وتعتبر هذه الظروف أفضل بيئـة مناسبـة لمعظم هجن الذرة الثناميــة. 